\title{
NON-TECHNICAL SKILLS: INPUT TO BACHELOR OF SCIENCE IN BUSINESS ADMINISTRATION GRADUATES' EMPLOYABILITY
}

\author{
Elaine Joy C. Apat, Julieta A. Sumague \\ Laguna State Polytechnic University, Laguna, Philippines \\ *Corresponding Author Email: elaine.apat@gmail.com, juliearjona07@gmail.com
}

This is an open access article distributed under the Creative Commons Attribution License, which permits unrestricted use, distribution, and reproduction in any medium, provided the original work is properly cited

\section{ARTICLE DETAILS}

\section{Article History:}

Received 16 July 2019

Accepted 20 August 2019

Available online 29 October 2019

\section{ABSTRACT}

This study was conducted to determine the non-technical skills of the Bachelor of Science in Business Administration graduates as input to their employability. The respondents used are supervisors in the company, in terms of industry they are working, majority are in the banks and Business Process Outsourcing (BPO) and are regular employees. Results of the study showed that among the non-technical skills which are communication, cooperation and work-ing with others, interaction, decision making and action, and self-management are highly ob-served. On the work retention and promotion potential as variables in employability are strongly agree. Findings showed that test of correlation between non-technical skills on com-munication, interaction, and decision making and action to the employability is not signifi-cant. The proponents concluded that there is a positive correlation between non-technical skills on communication, interaction, decision making to the employability while in coopera-tion and selfmanagement have no significant relationship to employability.

\section{KEYWORDS}

Bachelor of Science in Business Administration Graduates, employability, non-technical skills

\section{INTRODUCTION}

"Education is our passport to the future, for tomorrow belongs to those who prepare for it today", a quote from Malcolm X that explain a deeper meaning of how important the education is to every person in the world. Education can take you anywhere. It is as vital to the point it became a right of every child. A better future does not just exist instead effort and preparation are needed. Education facilitates learning, a process of acquisition of knowledge, skills, values, and habits. Educational stages are subdivisions of formal learning, typically covering early childhood education, primary education and tertiary (or higher) education. Each stage taught the student into different things. Started from simple counting, reading, computing, then go beyond comprehension, harder mathematical equations and learnt from different subjects for the preparation for their college.

While employees with a high school education may secure jobs with good benefits college graduates typically fare better entering higher-level careers with greater salaries. They are also more likely to receive promotions earn raises and develop reasoning and communication skills that can be applied to their jobs. Securing a job is very difficult often, college graduates are challenged for job hunting and securing it. College graduates tend to transfer jobs from time to time once they are not satisfied and if the workplace sees that their employee is lacking for some skills needed to their job requirement. A bachelor's degree in business can prepare students for many different jobs in the business marketplace. The degree itself is globally competitive and it is indeed always in demand all around and outside the country. In today's competitive market you know employers are looking for more in their business management hires: more know-how, more abilities, and more potential. But what specific knowledge and skill sets do employers prize more in prospective employees? Most of the employers today are looking for skills that focused on the communication, interpersonal, and self-management.

\section{LITERATURE REVIEW}

There is a clear set of definable competencies, in terms of things that a person knows how to do or facts that they have committed to memory, in areas like medicine nursing, business, law and accountancy. In some other fields, habits of thinking, the ability to take a critical approach to a problem and then choose and implement the right research strategy to solve it are more important than functional competency or facts. In addition, no matter how closely, universities/colleges and employers are there will always be tensions when it comes to competencies, skills, and attitudes towards work issues. Employers tend to want things to be done their way while universities expect students to develop and exercise critical judgement. Either employers or universities may be ahead in terms of technical or theoretical innovation. Of course, university programs leaders should always keep their finger on the pulse of change in the field(s) their students hope to seek work in.

According to a study, Universities and Colleges need to respond and often employers need to help of researchers to shape and understand developments [1]. Making sure students know how to do what will be expected of them-for example, having the ability to use key software packages or analytical tools-there is a must if university programs are to claim relevance to students' later job success. Non-technical skills or soft skills are necessary for career enhancement of an individual since these skills are personal traits that enhance the individual's interaction, communication skills, and job performance [2]. Moreover, soft skills often referred to as interpersonal, human, people or behavioral skills and place emphasis on personal behavior and managing relationships among people 
[3]. Modern professional practice requires not only technical/hard skills, but also high-level generic or soft professional skills. As a result, companies nowadays may not only concern with technical skills of the business administration graduates, but they expect the future employees to have appropriate soft skills.

I addition, according to Higher Education Academy Engineering Subject Centre, soft skills and personal attributes make graduates more likely to gain employment and be successful in their chosen occupations [4]. Moreover, companies may not be concerned with the technical skills of their entry-level managers because they will train them according to their company standards, but most companies want their future managers to have the soft skills to be successful within the organization's environment [5]. However, hard skills or technical skills must be disregarded. It deals with the data and administrative skills as defined by some researchers [6]. It refers to the technical knowledge and abilities that an individual should have to carry out the tasks associated with the position.

Development of the non-technical skills is what educators want to pursue for the demand of the employers for the Business Administration graduates to have. Technical skills can be learned in a long period of time compared to non-technical skills can be learned for months or so. As the Australian Learning and Teaching Council, non-technical skills are deemed very important to employers according to a recent report into the changing skills set for professional business administration graduates. In the study investigated the emphasis placed on technical and generic skills development from both the graduates and employers' perspective [7].

Their study found that employers required a broad range of generic skills that graduates indicated were not being adequately taught in business courses. Employers' perspective the greatest areas of skills divergence were those of team skills, leadership potential, verbal communication, and interpersonal skills of graduates. This study is anchored on the skills theory of David Burkus which state that skills theories are leader-centric and focus on what characteristics about them are effective. The two primary theories to develop skills theory were Katz' three-skill approach and Mumford's skills model of leadership also known as a capacity model. Three-skill approach argued that effective leadership required three skills: technical, human, and conceptual skills. Katz even mentioned the higher someone was in the organization, the less technical skills were required to fill the position and more conceptual skills were required, the lower the position in the organization more technical skills and less conceptual skills were required. However human skills are always required no matter the level or the position in the organization.

\section{CONCEPTUAL FRAMEWORK}

\begin{tabular}{|c|c|}
\hline Dependent Variables & Independent Variable \\
\hline $\begin{array}{l}\text { Profile of the Respondents } \\
\text { - Company Name } \\
\text { - Position } \\
\text { - Current Position } \\
\text { - Status of Employment } \\
\text { - Length of Service of } \\
\text { Alumni } \\
\text { Non-Technical skills } \\
\text { - Communication } \\
\text { - Cooperation and } \\
\text { working with others } \\
\text { - Interaction } \\
\text { - Decision making and } \\
\text { action } \\
\text { - Self-management }\end{array}$ & $\begin{array}{l}\text { Employability of BSBA } \\
\text { Graduates as to: } \\
\text { - Work Retention } \\
\text { - Promotion Potential }\end{array}$ \\
\hline
\end{tabular}

Figure 1: Research Paradigm

\section{STATEMENT OF THE PROBLEM}

This study was aimed to determine the non-technical skills of the BSBA graduates of LSPU-SPCC.

Specifically, it was sought to answer the following questions:
1.1 company name

1.2 position

1.3 current position of alumni

1.4 status of employment of alumni and

1.5 length of service of the alumni?

2. What is the level of their non-technical skills as to:

2.1 communication (listening, clarity, sharing information, assertiveness)

2.2 cooperation and working with others

2.3 interaction

2.4 decision making and action and

2.5 self-management (motivation, confidence, initiative)

3. What is the level of employability of BSBA graduates as to:

3.1 work retention and

3.2 promotion potential?

4. Is there a significant relationship between the non-technical skills and the employability of BSBA graduates?

\section{HYPOTHESIS}

There is no significant relationship between the non-technical skills and the employability of Bachelor of Science in Business Administration graduates.

\section{RESEARCH METHODOLOGY}

This paper is a descriptive research and used purposive sampling technique and is limited to Supervisors or Heads of Bachelor of Science in Business Administration graduates from the year 2014 to 2018. Researchers chose 30 different organizations either public or private. Selfmade questionnaires were made and given to evaluate the graduates with non-technical skills and employability. Frequency count was used to determine the profile of the respondents. Mean was used to measure the non-technical skills of BSBA graduates and their employability. Pearson-r was used to identify the significant relationship between the non-technical skills and employability. For Part II of the survey questionnaire Point Likert Scale 4-Highly Observed; 3-Observed; 2-Slightly Observed; and 1Not Observed were used to measure the non-technical skills of BSBA graduates. On the other hand, rating such as;4- Strongly Agree; 3-Agree; 2Disagree; and 1-Strongly Disagree were used to measure the employability of BSBA graduates

\subsection{Part I: Profile of the Respondents}

The respondents of the study in terms of position in the company consist of 9 as supervisory, 12 as senior staff, and 9 as junior staff: in terms of industry they are working, 7 is in BPO, 13 in banking, 2 in education, and 8 in sales and manufacturing; in terms of status of employment, 22 are regular employees, 5 are probationary, and 3 are contractual; and in terms of length in service, 11 are working for 3 years, 10 for 2 years, 5 for 1 year, and 4 for less than 1 year in service.

\subsection{Part II: Non-Technical Skills}

Table 1: Communication (listening clarity sharing information assertiveness)

\begin{tabular}{|l|c|c|}
\hline \multicolumn{1}{|c|}{ Indicators } & Mean & $\begin{array}{c}\text { Verbal } \\
\text { Interpretation }\end{array}$ \\
\hline $\begin{array}{l}\text { Demonstrate effective verbal } \\
\text { communication and listening skills. }\end{array}$ & 3.47 & $\begin{array}{c}\text { Highly } \\
\text { Observed }\end{array}$ \\
\hline $\begin{array}{l}\text { Comprehends and follows verbal } \\
\text { instructions. }\end{array}$ & 3.37 & $\begin{array}{c}\text { Highly } \\
\text { Observed }\end{array}$ \\
\hline $\begin{array}{l}\text { Listens to others in an active and attentive } \\
\text { manner. }\end{array}$ & 3.57 & $\begin{array}{c}\text { Highly } \\
\text { Observed }\end{array}$ \\
\hline $\begin{array}{l}\text { Shares relevant information to supervisors } \\
\text { and co-workers. }\end{array}$ & 3.40 & $\begin{array}{c}\text { Highly } \\
\text { Observed }\end{array}$ \\
\hline $\begin{array}{l}\text { Shows self-confidence in expressing } \\
\text { opinions. }\end{array}$ & 3.57 & $\begin{array}{c}\text { Highly } \\
\text { Observed }\end{array}$ \\
\hline \multicolumn{1}{|c|}{ Overall Mean } & $\mathbf{3 . 4 7}$ & $\begin{array}{c}\text { Highly } \\
\text { observed }\end{array}$ \\
\hline
\end{tabular}

1. What is the profile of the respondents in terms of: 
The table shows that all the indicators in communication skills are highly observed having a mean of 3.37 as the lowest and 3.57 as the highest and with an overall mean of 3.47. It can be implied that communication is an skills element and plays an important task in the business world. More so in the most progressive companies, managers are looking for peoples' ability to communicate clearly and openly, and to listen and respond empathetically.

Table 2: Cooperation and Working with Others

\begin{tabular}{|l|c|c|}
\hline \multicolumn{1}{|c|}{ Indicators } & Mean & $\begin{array}{c}\text { Verbal } \\
\text { Interpretation }\end{array}$ \\
\hline $\begin{array}{l}\text { Manages and resolves conflict to a team } \\
\text { atmosphere. }\end{array}$ & 3.60 & $\begin{array}{c}\text { Highly } \\
\text { Observed }\end{array}$ \\
\hline $\begin{array}{l}\text { Emphasizes the importance of having a } \\
\text { collective sense of mission. }\end{array}$ & 3.53 & $\begin{array}{c}\text { Highly } \\
\text { Observed }\end{array}$ \\
\hline Suggests new ways of doing things. & 3.47 & $\begin{array}{c}\text { Highly } \\
\text { Observed }\end{array}$ \\
\hline $\begin{array}{l}\text { Respects input and ideas from other } \\
\text { sources and people. }\end{array}$ & 3.50 & $\begin{array}{c}\text { Highly } \\
\text { Observed }\end{array}$ \\
\hline $\begin{array}{l}\text { Controls emotions in a manner } \\
\text { appropriate for work. }\end{array}$ & 3.67 & $\begin{array}{c}\text { Highly } \\
\text { Observed }\end{array}$ \\
\hline \multicolumn{1}{|c|}{ Overall Mean } & $\mathbf{3 . 5 5}$ & $\begin{array}{c}\text { Highly } \\
\text { Observed }\end{array}$ \\
\hline
\end{tabular}

The table displays that all indicators in cooperation and working with others also are highly observed with a total mean of 3.33. Cooperation is essential in all aspects of life and nearly every job in business today entails at least some joint efforts by members to work together. This makes cooperation an essential skill in most sectors of the work world.

Table 3: Interaction

\begin{tabular}{|l|c|c|}
\hline \multicolumn{1}{|c|}{ Indicators } & Mean & $\begin{array}{c}\text { Verbal } \\
\text { Interpretation }\end{array}$ \\
\hline $\begin{array}{l}\text { Loves doing his/her job with the } \\
\text { supervisors and colleagues in the } \\
\text { department he/she belongs. }\end{array}$ & 3.47 & $\begin{array}{c}\text { Highly } \\
\text { Observed }\end{array}$ \\
\hline $\begin{array}{l}\text { Participates and supports the department } \\
\text { especially when it conducts different } \\
\text { activities. }\end{array}$ & 3.33 & $\begin{array}{c}\text { Highly } \\
\text { Observed }\end{array}$ \\
\hline $\begin{array}{l}\text { Effectively participates in the meeting or } \\
\text { group settings. }\end{array}$ & 3.23 & $\begin{array}{c}\text { Highly } \\
\text { Observed }\end{array}$ \\
\hline $\begin{array}{l}\text { Respects input and ideas from other } \\
\text { sources and people. }\end{array}$ & 3.27 & $\begin{array}{c}\text { Highly } \\
\text { Observed }\end{array}$ \\
\hline $\begin{array}{l}\text { Brainstorms/develops option and ideas } \\
\text { with co-workers. }\end{array}$ & 3.43 & $\begin{array}{c}\text { Highly } \\
\text { Observed }\end{array}$ \\
\hline \multicolumn{1}{|c|}{ Overall Mean } & $\mathbf{3 . 5 0}$ & $\begin{array}{c}\text { Highly } \\
\text { observed }\end{array}$ \\
\hline
\end{tabular}

The table presents that four of the indicators in interaction are highly observed while only one is observed with an overall mean of 3.23. According to a study as cited by Laurence Ong, revealed that positive interpersonal interaction is the key to success while working or otherwise lack of interpersonal skills would affect our work efficiencies [8]. It is very important when we can increase awareness on our interpersonal relationship with colleagues will affect our daily work.

Table 4: Decision Making and Action

\begin{tabular}{|l|c|c|}
\hline \multicolumn{1}{|c|}{ Indicators } & Mean & $\begin{array}{c}\text { Verbal } \\
\text { Interpretation }\end{array}$ \\
\hline Seeks out and utilizes resources. & 3.07 & $\begin{array}{c}\text { Highly } \\
\text { Observed }\end{array}$ \\
\hline $\begin{array}{l}\text { Open to new experiences and takes } \\
\text { appropriate risks. }\end{array}$ & 3.27 & $\begin{array}{c}\text { Highly } \\
\text { Observed }\end{array}$ \\
\hline $\begin{array}{l}\text { Breaks down complex tasks/problems into } \\
\text { manageable pieces. }\end{array}$ & 3.50 & $\begin{array}{c}\text { Highly } \\
\text { Observed }\end{array}$ \\
\hline
\end{tabular}

\begin{tabular}{|l|c|c|}
\hline $\begin{array}{l}\text { Shows promptness and firmness in } \\
\text { deciding on important matters. }\end{array}$ & 3.30 & $\begin{array}{c}\text { Highly } \\
\text { Observed }\end{array}$ \\
\hline $\begin{array}{l}\text { Participates in the organization's decision } \\
\text { making. }\end{array}$ & 3.33 & $\begin{array}{c}\text { Highly } \\
\text { Observed }\end{array}$ \\
\hline \multicolumn{1}{|c|}{ Overall Mean } & $\mathbf{3 . 2 9}$ & $\begin{array}{c}\text { Highly } \\
\text { Observed }\end{array}$ \\
\hline
\end{tabular}

The table shows that the first indicator is observed with a mean of 3.07 while the rest are highly observed having a mean of 3.27 as the lowest and a mean of 3.50 as the highest. According to Hewitt, in modern businesses that always keep their employees well informed about all important affairs of their organizations and involve them in decision making at all levels can utilize the talents of the employees [9].

Table 5: Self-Management (motivation confidence \& initiative)

\begin{tabular}{|l|c|c|}
\hline \multicolumn{1}{|c|}{ Indicators } & Mean & $\begin{array}{c}\text { Verbal } \\
\text { Interpretation }\end{array}$ \\
\hline Works on complex matters. & 3.37 & $\begin{array}{c}\text { Highly } \\
\text { Observed }\end{array}$ \\
\hline $\begin{array}{l}\text { Accepts responsibility for mistakes and } \\
\text { learns from experiences. }\end{array}$ & 3.33 & $\begin{array}{c}\text { Highly } \\
\text { Observed }\end{array}$ \\
\hline $\begin{array}{l}\text { Demonstrates assertive but appropriate } \\
\text { behaviour. }\end{array}$ & 3.43 & $\begin{array}{c}\text { Highly } \\
\text { Observed }\end{array}$ \\
\hline Asks pertinent and purposeful questions. & 3.47 & $\begin{array}{c}\text { Highly } \\
\text { Observed }\end{array}$ \\
\hline $\begin{array}{l}\text { Prompt in showing up to work and } \\
\text { meetings. }\end{array}$ & 3.33 & $\begin{array}{c}\text { Highly } \\
\text { Observed }\end{array}$ \\
\hline \multicolumn{1}{|c|}{ Overall Mean } & $\mathbf{3 . 3 9}$ & $\begin{array}{c}\text { Highly } \\
\text { Observed }\end{array}$ \\
\hline
\end{tabular}

Table depicts that all the indicators on self-management are highly observed with 3.33 as the lowest and 3.47 as the highest with the overall mean of 3.31. It can be implied that though self-management is difficult to learn abilities in business in the workplace, and in our personal life it is one of the management best practices for those people who are decided to become more productive employees.

\subsection{Part III. Employability}

Table 6: Work Retention

\begin{tabular}{|l|c|c|}
\hline \multicolumn{1}{|c|}{ Indicators } & Mean & $\begin{array}{c}\text { Verbal } \\
\text { Interpretation }\end{array}$ \\
\hline $\begin{array}{l}\text { Takes the opportunities to learn } \\
\text { new skills or knowledge. }\end{array}$ & 3.63 & $\begin{array}{c}\text { Strongly } \\
\text { Agree }\end{array}$ \\
\hline $\begin{array}{l}\text { Accepts responsibility for mistakes } \\
\text { and learns from experiences. }\end{array}$ & 3.67 & $\begin{array}{c}\text { Strongly } \\
\text { Agree }\end{array}$ \\
\hline $\begin{array}{l}\text { Feel free to speak his/her mind, } \\
\text { shares ideas and addresses conflict. }\end{array}$ & 3.63 & $\begin{array}{l}\text { Strongly } \\
\text { Agree }\end{array}$ \\
\hline $\begin{array}{l}\text { Contributes to the attainment of } \\
\text { company's goals and objectives. }\end{array}$ & 3.50 & $\begin{array}{c}\text { Strongly } \\
\text { Agree }\end{array}$ \\
\hline $\begin{array}{l}\text { Knows what are expected from } \\
\text { him/her. }\end{array}$ & 3.53 & $\begin{array}{c}\text { Strongly } \\
\text { Agree }\end{array}$ \\
\hline \multicolumn{1}{|c|}{ Overall Mean } & $\mathbf{3 . 5 9}$ & $\begin{array}{c}\text { Strongly } \\
\text { Agree }\end{array}$ \\
\hline
\end{tabular}

Table shows that all the indicators on work retention is interpreted as strongly agree. The result shows that modern corporate requirements are looking specifically for those candidates who can add value to their organization with their soft skills and the ability to develop and use soft skills [6]. Whereas according to a study, employees who are happy and satisfied with their jobs are more dedicated towards their work and always put their effort to improve their organizational customers' satisfaction [10]. 
Table 7: Promotion Potential

\begin{tabular}{|c|c|c|}
\hline Indicators & Mean & $\begin{array}{c}\text { Verbal } \\
\text { Interpretation }\end{array}$ \\
\hline $\begin{array}{l}\text { Performs at an acceptable level of } \\
\text { competence }\end{array}$ & 3.60 & $\begin{array}{l}\text { Strongly } \\
\text { Agree }\end{array}$ \\
\hline $\begin{array}{l}\text { Demonstrates ability to perform at the } \\
\text { next higher-grade level }\end{array}$ & 3.53 & $\begin{array}{l}\text { Strongly } \\
\text { Agree }\end{array}$ \\
\hline $\begin{array}{l}\text { Possesses skills that are desirable for } \\
\text { higher-level jobs. }\end{array}$ & 3.43 & $\begin{array}{l}\text { Strongly } \\
\text { Agree }\end{array}$ \\
\hline $\begin{array}{l}\text { Takes on more responsibility when } \\
\text { opportunity arises. }\end{array}$ & 3.70 & $\begin{array}{l}\text { Strongly } \\
\text { Agree }\end{array}$ \\
\hline $\begin{array}{l}\text { Earns the trust of the colleagues and } \\
\text { supervisor. }\end{array}$ & 3.57 & $\begin{array}{l}\text { Strongly } \\
\text { Agree }\end{array}$ \\
\hline Overall Mean & 3.57 & $\begin{array}{l}\text { Strongly } \\
\text { Agree }\end{array}$ \\
\hline
\end{tabular}

Table shows that all indicators on potential promotion are interpreted also as strongly agree with a mean of 3.43 as the lowest and 3.70 as the highest with an overall mean of 3.57 .

Table 8: Correlation Between Non-Technical Skills and Employability

\begin{tabular}{|l|c|c|c|}
\hline \multicolumn{1}{|c|}{ Non-Technical Skills } & R-Value & P-Value & $\begin{array}{c}\text { Verbal } \\
\text { Interpretation }\end{array}$ \\
\hline Communication & 0.45 & 0.01 & $\begin{array}{c}\text { Strongly } \\
\text { Agree }\end{array}$ \\
\hline $\begin{array}{l}\text { Cooperation and Working with } \\
\text { Others }\end{array}$ & 0.33 & 0.07 & $\begin{array}{c}\text { Strongly } \\
\text { Agree }\end{array}$ \\
\hline Interaction & 0.41 & 0.02 & $\begin{array}{c}\text { Strongly } \\
\text { Agree }\end{array}$ \\
\hline Decision Making and Action & 0.40 & 0.03 & $\begin{array}{c}\text { Strongly } \\
\text { Agree }\end{array}$ \\
\hline Self-Management & 0.17 & 0.36 & $\begin{array}{c}\text { Strongly } \\
\text { Agree }\end{array}$ \\
\hline
\end{tabular}

\section{SALIENT FINDINGS}

Non-technical skills on communication, interaction, and decision making have a significant relationship with an R-value of 0.41 and 0.40 and Pvalue of $0.01,0.02$, and 0.03 respectively. Development of the nontechnical skills is what educators want to pursue for the demand of the employers for the Business Administration graduates to have [11]. Technical skills can be learned in long period of time compared to non- technical skills that can be learned for months or so. As the Australian Learning and Teaching Council, non-technical skills are deemed very important to employers according to recent report into the changing skills set for professional business administration graduates. While cooperation and working with others and self-management have no significant relationship to employability with R-value of 0.33 and 0.17 and P-value of 0.07 and 0.36 respectively.

\section{CONCLUSIONS}

Based on the findings of the study the proponents concluded the following:

1. There is a positive correlation between the non-technical skills or soft skills on communication, interaction, and decision making to the employability. Therefore, students of the Bachelor of Science in Business Administration may equip themselves with non-technical skills or soft skills demanded by the profession. These three skills pave the way for career promotion and professional advancement. In any way both employers and employees may benefit from enhancing further these skills.

2. Both the non-technical skills on cooperation and self-management have no significant relationship to the employability.

\section{REFERENCES}

[1] Waltz, M. 2009. Developing Soft Skills in Students, Retrieved January from http://108.cgpublisher.com/proposals/64/index-html

[2] Dhobale, R.S. 2009. Developing Soft Skills in Students, Retrieved January from http://108.cgpublisher.com/proposal/64/index-html

[3] Rainsbury. 2002. Professionals' Perception of Soft Skills Needed.

[4] Education is important. Retrieved from: http://www.positivityblog.com/quotes-on-education/

[5] Future Jobs of BSBA Graduates. Retrieved from: http://online.lsua.edu/articles/business/five-jobs-bsba-degree.aspx

[6] Richard, S. 2013. Importance of Soft Skills: The Incorporation of Soft Skills into Accounting Curricula, Emerald Group Publishing Limited.

[7] Jackling, B. 2009. Meeting Expectations of Employers. An International Journal, 18 (4/5), pp. 369-385

[8] Ong, L. A Study of the Importance of Non-Technical Skills for Accounting Fresh Graduates in Malaysia"

[9] Hewitt, J. 2000. High Performance Workplaces: The Role of Employee Involvement, www.berr.gov.uk/files/file 26555.pdf

[10] Denton, J. 2000. Using Web-based projects in a system design and development course. Journal of Computer Information Systems, 40 (3), pp.85-87

[11] Burkus, D. 2010. Leaders Team and Develop their Skills and Style 